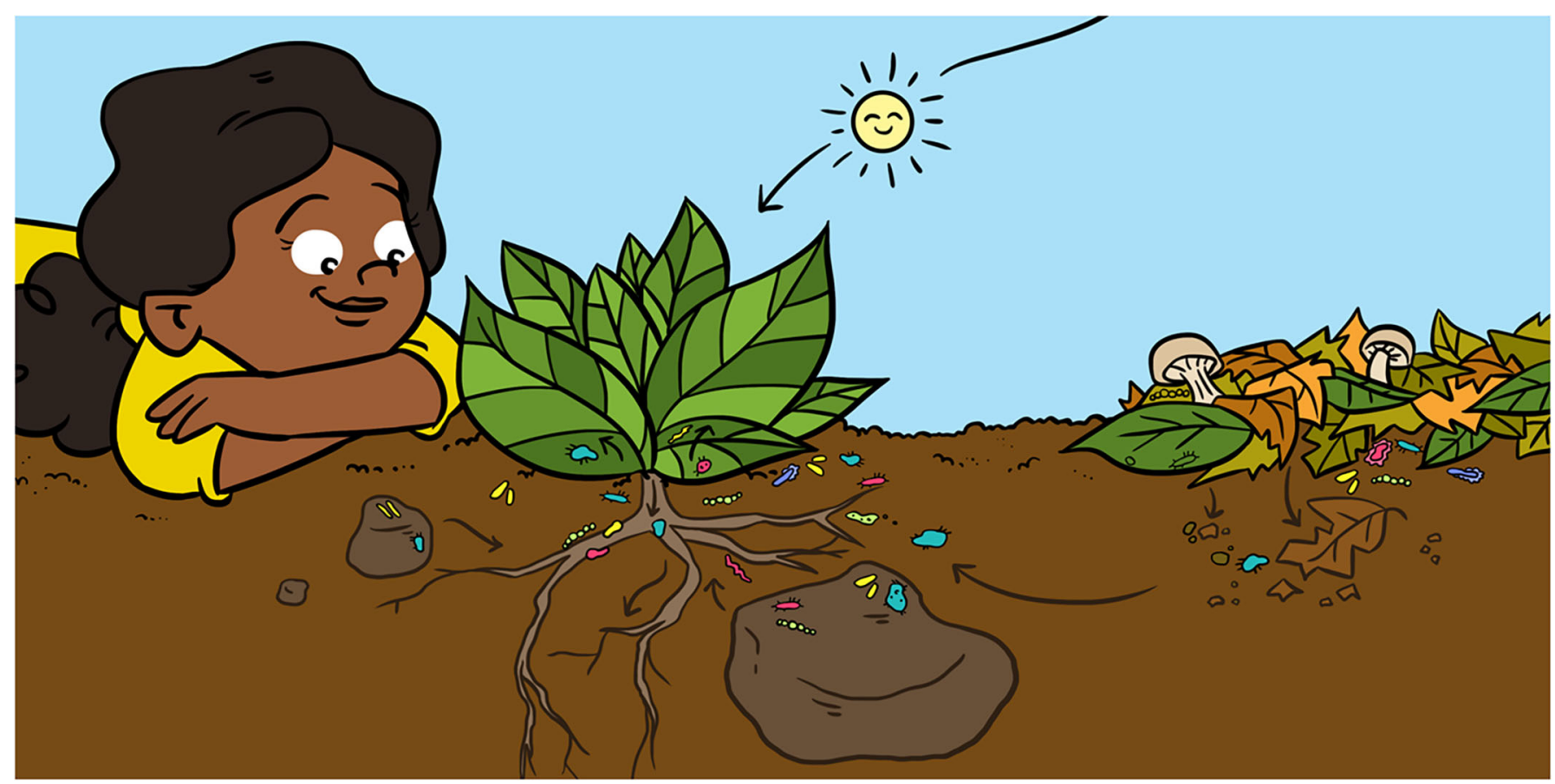

\title{
WHO FEEDS THE PLANTS? MICROBES!
}

\section{Aline Lacaze ", Antoine Zboralski and David L. Joly}

Biology Department, Université de Moncton, Moncton, NB, Canada

YOUNG REVIEWERS:

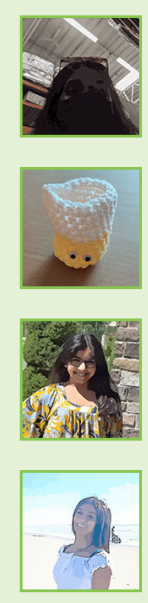

\section{MEHA}

AGE: 15

NIVEDITA

AGE: 14

SHREEYA

AGE: 11

SHRIYA

AGE: 13

\section{MICROBES}

Tiny living organisms such as bacteria or fungi, also called microorganisms. Some microbes cause plant diseases, but others are helpful.
Plants get their food from the soil they grow in. But this food is only available thanks to a great diversity of microbes, especially bacteria and fungi, that can chemically and mechanically transform materials in the soil into nutrients. These soil microbes have received a lot of attention from scientists all around the world, because these organisms could improve the way we grow our food and could make agriculture more sustainable. In this article, we explore some of the main mechanisms used by these microbes to feed plants.

\section{INTRODUCTION}

Beneath the surface of the Earth lives a tremendous diversity of microbes, including many species of bacteria and fungi. These organisms vary in shape and size, and most of them are not even as thick as a hair. We cannot see soil microbes with our eyes, but they play a fundamental role in our lives: they feed the plants that we grow for food. In other words, soil microbes are essential for us to live on this planet. Soil microbes have evolved many different ways to help plants grow, such as breaking down rocks, recycling dead matter, 
ROCK WEATHERING

the mechanical and chemical breakdown of rocks.

HYPHAE

Long, branching, tube-like structures of fungi that are used by the fungi to grow and find nutrients.

SAPROBIONTS

Any organism, especially a fungus or bacterium, that lives and feeds on dead matter. and establishing cooperative relationships with plants. Let us see how these tiny organisms carry out all these tasks.

\section{A TINY TASTE FOR ROCKS}

Plants cannot directly live on rocks because the nutrients in rocks are not available to them. The nutrients plants need are found in the soil and include elements like iron and potassium, or small molecules like phosphate or nitrate. These nutrients are the building blocks required for plants to grow, just like the food we eat is used to fuel our bodies.

In the beginning of their evolution, plants existed only as algae living in oceans. At least 420 million years ago, they started to settle on the land [1]. At that time, the land had just been formed from volcanic activity, meaning it was mainly rocky, and no soils were present to help plants grow. Luckily microbes were already present on the land and these microbes had the ability to get nutrients from rocks, through a process called rock weathering. The microbes made the nutrients previously trapped within rocks available for the new terrestrial plants, allowing these plants to thrive on land and helping to form soils for future generations of plants!

How do microbes perform rock weathering? They make specialized proteins and acids that can affect the first layers of rocks through chemical reactions. These reactions cause the release of tiny components of rocks that can then be taken up by microbes and plants (Figure 1). For instance, the bacterium Bacillus subtilis can release manganese from rocks in a form that is easy for plants to take up [2]. The fungus Talaromyces flavus is another example. This organism uses acid to alter rocks and extract magnesium and iron. Fungi have long, tubular structures called hyphae that they use to grow and to absorb nutrients. Talaromyces flavus uses the pressure from the tips of its hyphae to break rocks and reach interesting minerals [3]. This fungus grows into small cracks and then pushes to expand them. Both fungi and bacteria also produce small molecules that can bind iron and help to facilitate rock weathering. Many types of microbes can alter rocks, and those pioneering species were essential to the formation of soils and the ultimate creation of complex land-based ecosystems.

\section{MICROBIAL SCAVENGERS: GUARDIANS OF THE SOILS}

In the eighteenth century, the French chemist Antoine Lavoisier formulated the law of conservation of mass, as follows: "Nothing is lost, nothing is created, everything is transformed." This principle also applies to living organisms and is illustrated by microbes called saprobionts (from the Greek words sapros: rotting and biôn: living). Saprobionts can recycle elements by decomposing dead matter like 
Figure 1

Both bacteria and fungi help to feed plants by breaking down rocks to make the nutrients trapped within the rocks available to nearby plant roots. This process is called rock weathering. Microbes that perform rock weathering enrich soils with nutrients and help crops to grow better.

\section{PHOTOSYNTHESIS}

The process by which plants use sunlight to make sugars from carbon dioxide.

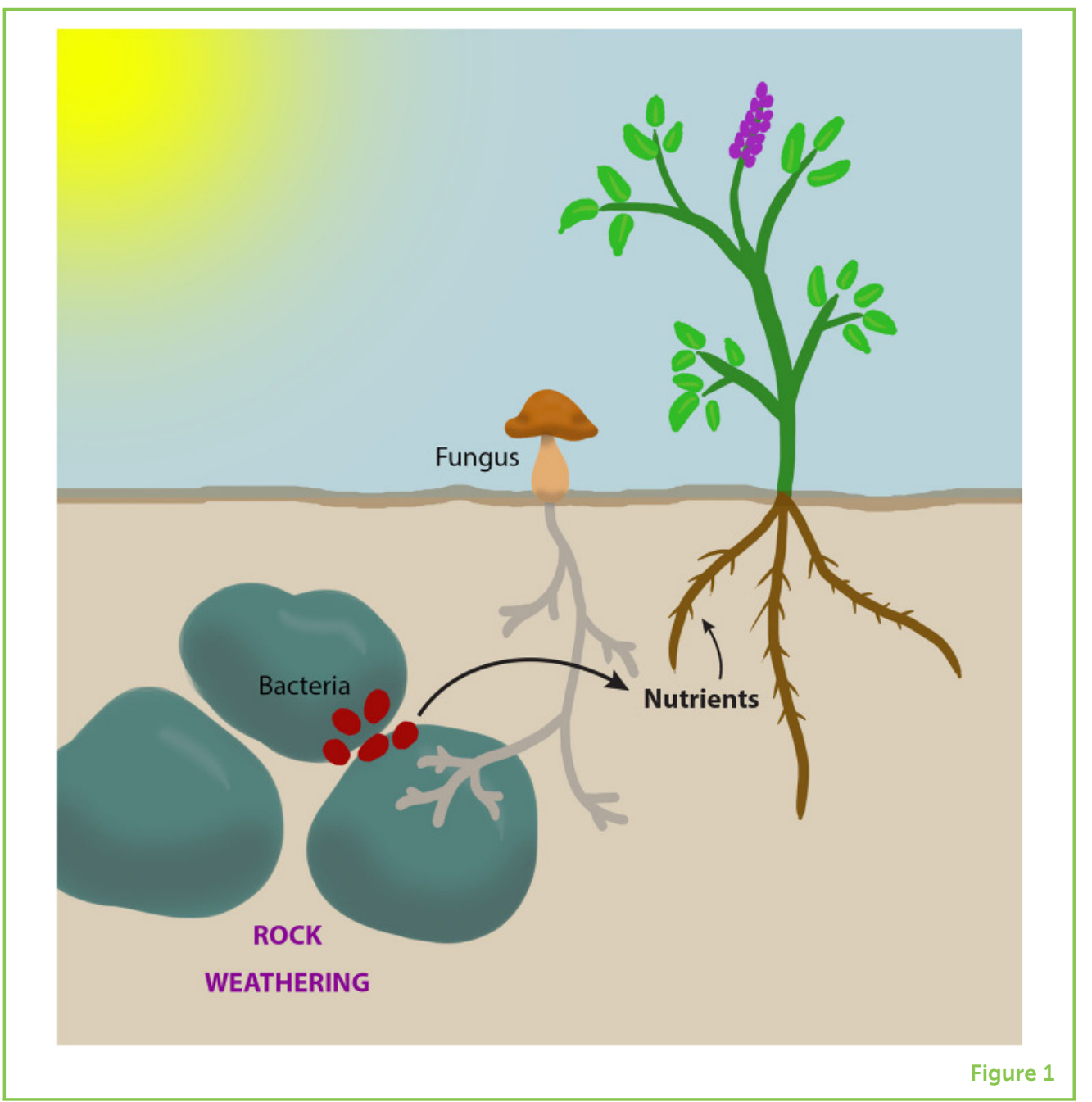

plant debris, and then taking up the resulting nutrients [4]. This process allows the saprobionts to get nutrients like sugars that they could not find otherwise. Plants are efficient sugar factories functioning on solar power. They combine molecules of carbon dioxide, using light as an energy source, in the process called photosynthesis. When plants die, the sugars they made can be used again by other organisms. Over time, more and more dead plant material accumulates on the ground and is recycled by saprobionts to form soils.

Saprobionts include an astonishing diversity of fungal and bacterial species and can live in a wide range of places. In farm soils, saprobionts are essential for transforming compost into forms of nutrients that can be used by crops (Figure 2). Without microbial saprobionts, compost would not be a good way to feed plants, because plants cannot directly collect nutrients from dead matter. In the absence of saprobionts, crops would not grow as well, and less food would be produced.

When extreme weather events occur, such as droughts caused by climate change, soil saprobionts can be affected and may not be as efficient at recycling dead matter. But if the saprobiont population is 


\section{Figure 2}

Saprobionts are soil bacteria and fungi that help to feed plants by decomposing dead material in the soil, such as compost. These microbes make the nutrients in the dead matter available for plants to absorb through their roots.

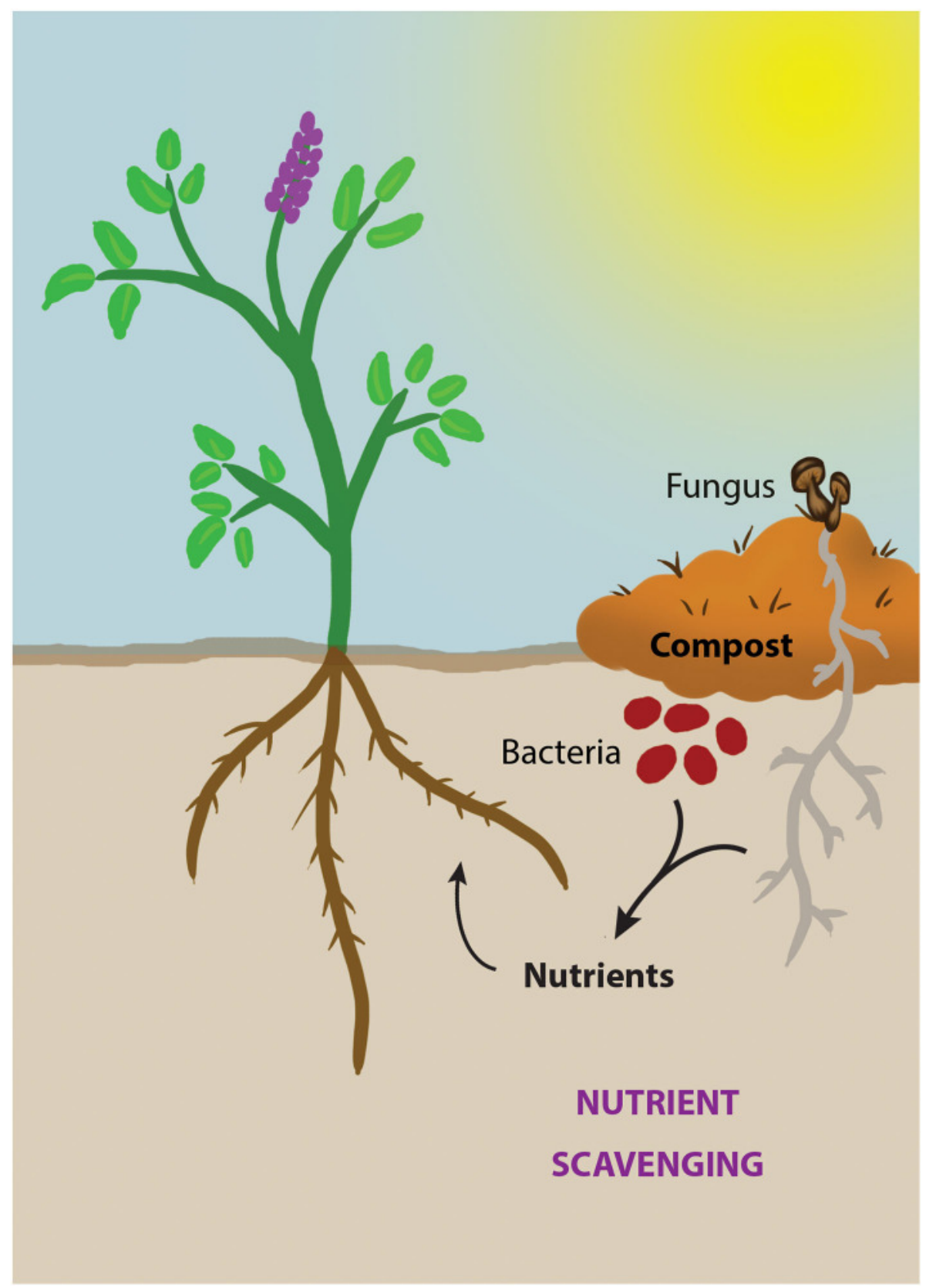

Figure 2

diverse enough, some species will not be as impacted as others by the extreme weather and will continue to degrade dead matter. So, it is important for soils to maintain a diverse population of saprobionts, so that matter can always be decomposed to feed other organisms and to keep nutrients flowing through ecosystems, supporting the crops we need to live.

\section{HIDDEN ROOT MARRIAGES}

The areas of the soil right next to plant roots are hotspots of microbial diversity. Some bacterial and fungal species find shelter inside the 
Figure 3

Both bacteria and fungi can form symbiotic relationships with plant roots, which feed the plants and benefit the microbes. Plants called legumes create nodules on their roots, in which certain bacteria can live and provide the plants with a form of nitrogen usable by plants. Mycorrhizae are structures created when plant roots form relationships with fungal hyphae. The hyphae transport nutrients from the soil to the plant roots. These symbioses greatly improve plant growth and health.

\section{SYMBIOSIS}

A close relationship between two organisms of different kinds which benefits both organisms.

\section{NODULE}

A swelling on the root of a leguminous plant that contains bacteria able to collect nitrogen from the air to give it to the plants.

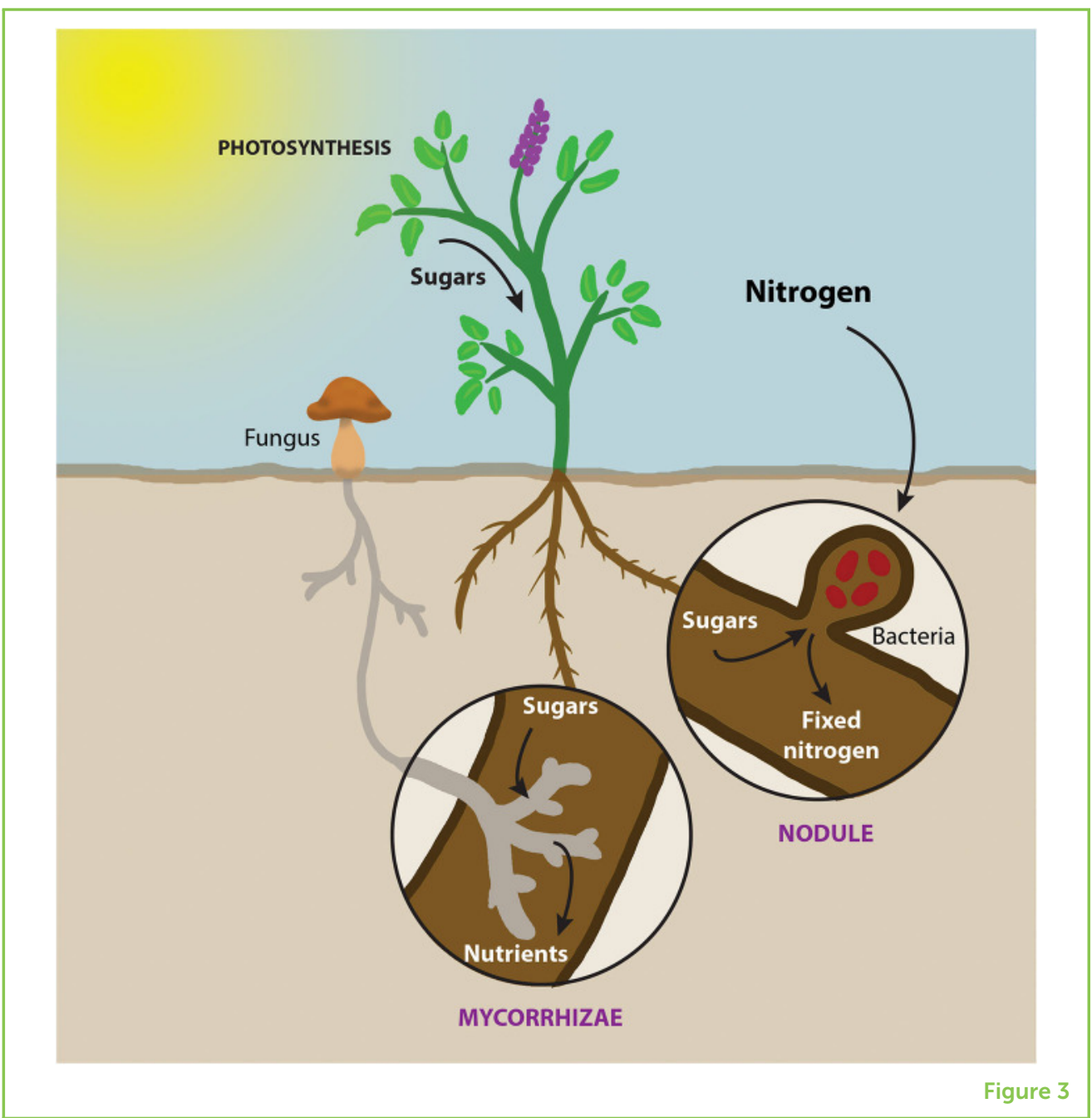

roots and get access to the sugars from photosynthesis, in exchange for providing nutrients and other services to the plant. This is called symbiosis: a relationship in which both organisms benefit, primarily by exchanging nutrients (Figure 3 ).

Legumes are a group of plants that includes crops like soybeans, peanuts, and peas. Legumes can establish a symbiotic relationship with bacteria of the genus Rhizobia. The legumes produce a new organ on their root surface for the bacteria to live in, called a nodule. Inside nodules, Rhizobia reproduce and are protected from environmental stresses. The bacteria also get some plant sugars, which they use to grow and to convert nitrogen from the air into ammonia, through chemical processes [5]. Ammonia is a source of nitrogen that the plants can use. Nitrogen is important for living organisms because it is an essential component of many biological molecules, such as DNA and proteins. Thus, plants benefit from the nitrogen provided by the bacteria in their root nodules. If Rhizobia species are present in the soil and nodulation occurs, farmers do not need to add as much additional nitrogen to the soil in the form of fertilizer as usual. 


\section{MYCORRHIZAE}

An association of a fungus and a plant in which the fungus lives within or on the outside of the plant's roots forming a symbiotic relationship.

Another symbiosis commonly found in ecosystems is established between plant roots and fungi. The structures formed from this type of symbiosis are called mycorrhizae (from the Greek words mýkés: fungi and rhiza: roots). More than $80 \%$ of land plants participate in this type of symbiosis [6]. Mycorrhizae are fascinating in their diversity and complexity, and new things are regularly being discovered about them. Basically, nutrients from the soil are transported to plant roots through the fungal hyphae. The hyphae can explore a greater volume of soil and can reach more distant soil areas than the plant's roots can, which increases the amount of nutrients available to the plants. Without mycorrhizae, plants would not be able to collect as many nutrients from the soil and would not grow as well. In return, plants share their sugars with the symbiotic fungi. Some mycorrhizal fungi can also weather rocks, as described earlier, to provide nutrients like phosphorus to their host plants. In crop fields, mycorrhization is critical for increasing the quantity of food that can be produced without the use of synthetic fertilizer.

\section{WHAT HAVE YOU LEARNED?}

So, now you know that soil microbes are critical in plant feeding in many ways. Although researchers have learned much about the important beneficial relationships between plants and microbes, many questions remain unanswered, such as, "Are bacteria and fungi always the main plant feeders in soil?"; "Which kinds of microbes are the best for promoting plant growth and health?"; and "How will climate change impact soil microbes?" These relationships are critical for building the kinds of soils that can sustain our agriculture. Also, microbial communities need to be diverse to face soil disturbances, such as those caused by climate change. It is important for scientists to better understand the complexity of plant feeding by microbes, so that we can face agricultural challenges.

\section{REFERENCES}

1. Pennisi, E. 2018. Land plants arose earlier than thought-and may have had a bigger impact on the evolution of animals. Science Mag. doi: 10.1126/science. aat3642

2. Samuels, T., Bryce, C., Landenmark, H., Marie-Loudon, C., Nicholson, N., Stevens, A. H., et al. 2020. Microbial weathering of minerals and rocks in natural environments. Biogeochem. Cycles Ecol. Drivers Environ. Impact 251:59-79. doi: 10.1007/978-94-009-3071-1_3

3. Hand, E. 2016. Iron-eating fungus disintegrates rocks with acid and cellular knives. Science Mag. doi: 10.1126/science.aaf4184

4. Jacoby, R., Peukert, M., Succurro, A., Koprivova, A., and Kopriva, S. 2017. The role of soil microorganisms in plant Mineral nutrition - current knowledge and future directions. Front. Plant Sci. 8:1617. doi: 10.3389/fpls.2017.01617

5. Wagner, S. C. 2011. Biological nitrogen fixation. Nat. Educ. Knowl. 3:15. 
6. Bonfante, P., Genre, A. 2010. Mechanisms underlying beneficial plant-fungus interactions in mycorrhizal symbiosis. Nat. Commun. 1:48. doi: 10.1038/nc omms1046

SUBMITTED: 08 September 2020; ACCEPTED: 16 July 2021;

PUBLISHED ONLINE: 13 August 2021.

EDITED BY: Phillip R. Myer, The University of Tennessee, Knoxville, United States

CITATION: Lacaze A, Zboralski A and Joly DL (2021) Who Feeds The Plants? Microbes! Front. Young Minds 9:604096. doi: 10.3389/frym.2021.604096

CONFLICT OF INTEREST: The authors declare that the research was conducted in the absence of any commercial or financial relationships that could be construed as a potential conflict of interest.

COPYRIGHT @) 2021 Lacaze, Zboralski and Joly. This is an open-access article distributed under the terms of the Creative Commons Attribution License (CC BY). The use, distribution or reproduction in other forums is permitted, provided the original author(s) and the copyright owner(s) are credited and that the original publication in this journal is cited, in accordance with accepted academic practice. No use, distribution or reproduction is permitted which does not comply with these terms.

\section{YOUNG REVIEWERS}
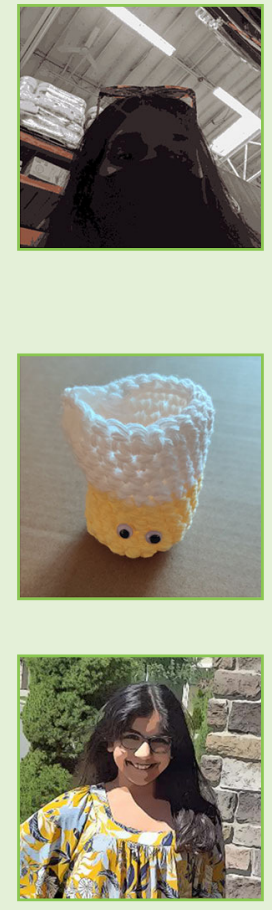

\section{MEHA, AGE: 15}

Hey, I am a sophomore in high school, and looking forward to a career in medicine. My hobbies include drawing, tennis, and just hanging out with friends! I also love to volunteer and give back to my community. I am excited to be a part of Frontiers for Young Minds, as I want my peers and other students to be able to access these great scientific accomplishments made every day.

\section{NIVEDITA, AGE: 14}

Hi I am Nivedita, my pronouns are she/her/hers, and I am excited to start this year off! A little about me, I love listening to music in my free time (Frank Ocean is a favorite (:) and I like to draw when I can. I like hanging out my friends, and my favorite subject is chemistry!

\section{SHREEYA, AGE: 11}

Hi my name is Shreeya. I live with my sister and my parents. In my free time I like to walk with friends, play board games, and doing karate. During this time, I have been keeping myself busy by talking with my friends, reading Harry Potter books, and finishing a 3D Hogwarts Puzzle.

\section{SHRIYA, AGE: 13}

$\mathrm{Hi}$, my name is Shriya. I live in the U.S. I am in eighth grade, and my favorite subjects 

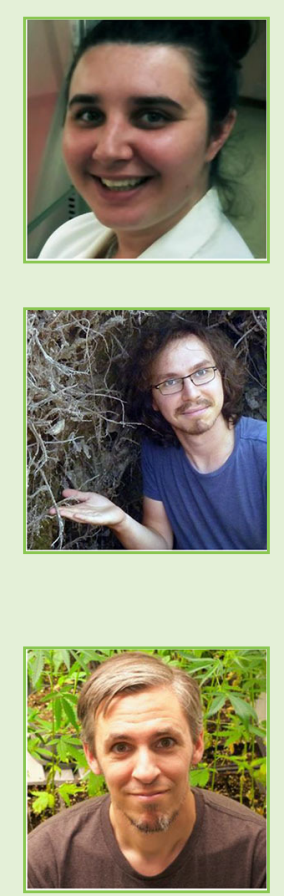

\section{ALINE LACAZE}

I graduated with a master's degree in plant genetics in France, and I am now pursuing a Ph.D. at the Universite de Moncton, New Brunswick, Canada. My research focuses on the late blight disease affecting potato plants. In the future, I would like to participate even more in science popularization. *aline.lacaze@ ahotmail.fr

\section{ANTOINE ZBORALSKI}

I am a Ph.D. student at the Université de Moncton, New Brunswick, Canada. I study underground plant-microbe interactions for improving plant health, which could make the way we grow our food more sustainable. I try to popularize my research to get people to better understand science. I am also an environmentalist involved in the local community to reduce our collective environmental footprint.

\section{DAVID L. JOLY}

I am an associate professor at the Universite de Moncton, New Brunswick, Canada. Research in my group revolves around plants and their associated microbes, and we use molecular biology tools and genomics to understand the interactions between those organisms. 